\title{
"OCHRONA" INFRASTRUKTURY GOSPODARCZEJ KWK „KATOWICE” PRZEZ SŁUŻBĘ BEZPIECZEŃSTWA W LATACH 80. XX WIEKU (ZE SZCZEGÓLNYM UWZGLĘDNIENIEM SPRAWY OBIEKTOWEJ O KRYPTONIMIE „CARBON”)
}

Piotr Franaszek (D) http://orcid.org/0000-0001-8572-7038

Uniwersytet Jagielloński w Krakowie

\author{
ABSTRACT \\ "PROTECTION" OF SILESIAN HARD COAL MINES BY THE STATE \\ SECURITY SERVICE IN THE 1980S (ON THE EXAMPLE OF HARD \\ COAL MINE "KATOWICE")
}

\begin{abstract}
During the entire period of the Polish People's Republic the Polish state security forces conducted surveillance operations of factories and other workplaces. All spheres of activity - political, social and economic - were controlled. These actions intensified in the 1980s, a unique period in the recent history of Poland, after the workers' strikes in August 1980 and the creation of the Independent Self-Governing Trade Union (NSZZ) "Solidarność". In response to the upheaval, the martial law was introduced, casting a grim shadow on the social and economic reality of the entire decade. Because of the importance of coal mining for the country's economic system, the activities of state security forces were meticulously carried out in the mines, including the hard coal mine "Katowice". All actions were controlled and recorded, not only those of workers who sympathized with powers hostile to the regime, but any event disturbing the rhythm of work - entirely coincidental events were tracked alongside possible cases of sabotage. Regardless of the real intentions behind these activities, this scrutiny of the state apparatus created a kind of chronicle of events that took place in the hard coal mine "Katowice" in the period under discussion.
\end{abstract}

Keywords: Katowice, industry, mining, hard coal mine, state Security Service.

Słowa kluczowe: Katowice, przemysł, górnictwo, kopalnia węgla kamiennego, Służba Bezpieczeństwa. 


\section{WSTĘP}

W okresie międzywojennym węgiel był podstawowym polskim surowcem energetycznym. Jego eksport dostarczał niezbędnych krajowi dewiz i dlatego często był nazywany „czarnym złotem”. Poziom produkcji węgla kamiennego na Górnym Śląsku sprzed wybuchu I wojny światowej osiągnięto w 1928 roku (ok. 40,6 mln ton)2 Po 1945 roku w polskim górnictwie węglowym wystąpił poważny niedobór siły roboczej spowodowany dewastacją zakładów Górnego Sląska przez wojska sowieckie oraz aresztowaniami śląskich górników wywożonych do kopalń Zagłębia Donieckiego, Zagłębia Kuźnieckiego, na Ural i zakładów położonych w innych częściach Związku Sowieckiego. Szacuje się, że deportacje te objęły około 13 000-15 000 osób. Braki w zakresie siły roboczej próbowano uzupełniać, zatrudniając emerytów i młodocianych, a także stosując przymusową pracę więźniów i jeńców niemieckich³ Pomimo tych trudności w kopalniach Górnego Śląska wydobyto w 1945 roku ponad 20 mln ton węgla, a w następnym roku już 47,3 mln, dzięki czemu Polska osiągnęła samowystarczalność w produkcji tego surowca ${ }^{4}$. Wobec niskiej wydajności pracy i słabych kwalifikacji przymusowo zatrudnionych górników wprowadzono pracę w niedzielę i święta. Upowszechniano też stachanowski ruch współzawodnictwa pracy, którego najbardziej znanym przedstawicielem stał się Wincenty Pstrowski, rębacz w kopalni „Jadwiga”s. Z jednej strony nadmiernie eksploatowano siłę roboczą, zaś $\mathrm{z}$ drugiej przyznawano pracownikom liczne przywileje socjalne, włącznie z wydaną w listopadzie 1949 roku Kartą Górnika, zapewniającą liczne uprawnienia, z których część istniała już wcześniej.

Realizacja planu sześcioletniego latach 1950-1955 wiązała się z przyspieszoną industrializacją, co sprzyjało intensywnemu rozwojowi przemysłu surowcowego i środków produkcji. Na Górnym Śląsku uruchomiono nowe kopalnie węgla kamiennego - „Ziemowit”, „Wesoła II” (później „Lenin”), „Kościuszko-Nowa”, „Julian” i „Nowy Wirek”. Zmiany, jakie nastąpiły w zarządzaniu gospodarką po Październiku 1956, sprzyjały bardziej racjonalnemu zarządzaniu także górnictwem węglowym. Na dużą skalę wprowadzano mechanizację prac górniczych, co przyczyniło

${ }^{1} \mathrm{~J}$. . Lazor, Import i eksport polskiego węgla w okresie międzywojennym [w:] Problemy energetyczne Polski, cz. I: Surowce, red. A. Jarosz-Nojszewska, W. Morawski, Warszawa 2016, s. 54, 56.

2 A. Jezierski, C. Leszczyńska, Historia gospodarcza Polski, Warszawa 1997, s. 280; Z. Landau, J. Tomaszews ki, Zarys historii gospodarczej Polski 1918-1939, Warszawa 1981, s. 89, 195.

${ }^{3}$ Z. Woźniczka, Represje na Górnym Ślasku po 1945, Katowice 2010, s. 261-301; idem, Dewastacja Górnego Śląska w 1945 roku przez Armię Czerwona [w:] Z dziejów przemystu po 1945 roku, red. E. Kościk, R. Klementow ski, Wrocław 2012, s. 128-129; Ł. Dwilewicz, Polityka energetyczna PRL [w:] Problemy energetyczne Polski, cz. I: Surowce, s. 94.

${ }^{4}$ A. Jezierski, C. Leszczyńska, op. cit., s. 422.

${ }^{5}$ E. Chojecka, Wincenty Pstrowski - zabrzański bohater pracy - tragiczny [w:] Praca, jej rola i funkcje społeczne na przestrzeni wieków w kontekście Europy Środkowej, red. A. Barciak, Katowice-Zabrze-Rybnik 2018, s. 158-162; Z. Woźniczka, Praca przymusowa w Polsce po 1945 roku [w:] Praca, jej rola i funkcje społeczne..., s. 271-292; A. Jezierski, C. Leszczyńska, op. cit., s. 422-423, 425; Ł. Dwilewicz, op. cit., s. 94. 
się do ograniczenia wielkości zatrudnienia pracowników dołowych. Wzrósł również poziom bezpieczeństwa prowadzonych prac. Na początku drugiej połowy lat 50. uruchomiono nowe kopalnie - „Porąbka” w Sosnowcu i „Halemba” w Rudzie Śląskiej, a w latach 1961-1965 oddano do użytku kopalnie „Szczygłowice” w Knurowie-Szczygłowicach, „Jastrzębie” w Jastrzębiu-Zdroju, „Staszic” w Katowicach i „Moszczenica” w Jastrzębiu-Moszczenicy. Rosło znaczenie Rybnickiego Okręgu Węglowego (ROW), w którym, pomimo trudnych warunków geologicznych, eksploatowano węgiel koksujący. Jedyną nową kopalnią uruchomioną $\mathrm{w}$ drugiej połowie lat 60. była kopalnia „Manifest Lipcowy” w Jastrzębiu. W efekcie w 1970 roku krajowe wydobycie węgla wynosiło $140,1 \mathrm{mln}^{6}$ ton $^{6}$.

W latach 70. XX wieku rozbudowano kopalnie „Ziemowit” i „Szczygłowice”. W 1971 roku uruchomiono kopalnię „Borynia” w Szerokiej, a trzy lata później kopalnię „XXX-lecia PRL” w Jastrzębiu-Pawłowicach i „Sląsk” w Rudzie Śląskiej. W 1975 roku oddano do eksploatacji kopalnię „Piast” w Tychach-Bieruniu Nowym. W wyniku podjętych działań w 1975 roku wydobycie osiągnęło 171,6 mln ton węgla. Rozpoczęto również budowę nowych kopalń w ROW, a w 1975 roku podjęto decyzję o utworzeniu Lubelskiego Zagłębia Węglowego. Wobec szybko rosnącego zadłużenia $\mathrm{w}$ drugiej połowie lat 70 . ponownie skierowano do górnictwa duży strumień nakładów inwestycyjnych, zakładając, że wzrost eksportu węgla umożliwi łatwiejszą spłatę kredytów. Tych planów nie udało się zrealizować wobec postępującego kryzysu społeczno-gospodarczego i chociaż w 1979 roku wydobyto ponad $200 \mathrm{mln}$ ton, to już w następnym roku wydobycie spadło do $193 \mathrm{mln}$. Jednocześnie następowała dezorganizacja pracy i rosło niezadowolenie pracowników kopalń. W warunkach ogólnokrajowego kryzysu w sierpniowych strajkach na Śląsku główną rolę odegrały najnowocześniejsze kopalnie Jastrzębia ${ }^{7}$.

Wśród górnośląskich kopalń do jednej z najstarszych należała kopalnia węgla kamiennego (KWK) „Katowice”. Została uruchomiona w 1823 roku i od jednego z pierwszych współwłaścicieli, Ignacego Ferdinanda Beyma nosiła nazwę „Ferdinand". Mieszkający w Tarnowskich Górach Ignacy Ferdinand von Beym był emerytowanym rotmistrzem i kupcem handlującym solą. Swoje starania o uruchomienie kopalni rozpoczął rok wcześniej:

Pod datą 8 sierpnia 1822 roku za pośrednictwem urzędnika Rewiru Górniczego Bytom-Wschód (Beuthen-Ost) wpłynął do Górnośląskiego Królewskiego Pruskiego Urzędu Górniczo-Hutniczego w Tarnowskich Górach wniosek o nadanie 1 kopalni znaleźczej i 600 miar pola górniczego pod nazwą „Ferdinand” w Bogucicach ${ }^{8}$.

Początkowo węgiel wydobywano sposobem odkrywkowym, ale wkrótce przystąpiono do budowy szybów wydobywczych. Pierwszymi górnikami pracującymi w kopalni byli wykwalifikowani robotnicy sprowadzeni z Westfalii i Zagłębia Wałbrzyskiego, a także z Olkusza i Wieliczki. Z czasem miejscowi chłopi nabywali

${ }^{6}$ Ł. Dwilewicz, op. cit., s. 99-112.

7 Ibidem, s. 124-130.

${ }^{8}$ R.W. Borowy, Wczoraj - dziś - jutro... kopalni „Katowice-Kleofas”. Historia węlem pisana, Katowice 1997, s. 376. 
stosownych kwalifikacji do wykonywania zawodu górnika9 ${ }^{9}$ W pierwszym roku działalności kopalni wydobyto 3100 ton węgla, a w latach 40. XIX wieku roczna produkcja utrzymywała się na poziomie około 6500 ton $^{10}$.

W 1922 roku kopalnia znalazła się w części Górnego Śląska przyłączonej do Polski, a jej nazwę spolszczono na „Ferdynand”. W 1936 roku kopalnię przemianowano na „Katowice”. W kwietniu 1937 roku w Katowicach zarejestrowano polską państwową spółkę akcyjną „Wspólnota Interesów Górniczo-Hutniczych”. Obejmowała ona pięć kopalń węgla kamiennego, w tym kopalnię „Katowice”"1. Po zajęciu Śląska przez Niemców w 1939 roku kopalnia przeszła pod zarząd niemieckiego Głównego Urzędu Powierniczego Wschód, a następnie została przekazana państwowemu koncernowi „Hermann Göring”, który utworzył filialne przedsiębiorstwo pod nazwą „Górnośląski Zarząd Kopalń i Zakładów Rzeszy Hermann Göring” z siedzibą w Katowicach. Kopalni przywrócono jej pierwotną nazwę „Ferdinand”. Po II wojnie światowej kopalnia została znacjonalizowana i poza latami 1953-1956, kiedy nazwano ją „Stalinogród”, utrzymała przedwojenną nazwę - „Katowice”12. W 1945 roku weszła w skład Katowickiego Zjednoczenia Przemysłu Węglowego. W 1982 roku słowo „zjednoczenia” zamieniono na „zrzeszenia”, a dwa lata później „zrzeszenia” na „gwarectwa”. W rezultacie od tego roku KWK „Katowice” należała do Katowickiego Gwarectwa Węglowego. Przez niecały miesiąc, na przełomie stycznia i lutego 1989 roku, KWK „Katowice” znajdowała się w strukturach Przedsiębiorstwa Eksploatacji Węgla „Północ" w Katowicach. W styczniu 1990 roku, w wyniku likwidacji struktur pośrednich pomiędzy kopalniami a ministerstwem uzyskały one osobowość prawną. Od 1 lipca 1993 roku KWK „Katowice” została włączona do Katowickiego Holdingu Węglowego, a w czerwcu 1996 roku połączona z KWK „Kleofas”. Od tego momentu zakład funkcjonował pod nazwą Kopalnia Węgla Kamiennego „Katowice-Kleofas”. Ostatecznie w 1999 roku KWK „Katowice” zakończyła swoją działalność ${ }^{13}$.

\section{KWK KATOWICE W LATACH 80. XX WIEKU}

W latach 80. XX wieku kopalnia rozciągnięta była pomiędzy katowickimi dzielnicami Zawodzie, Bogucice oraz Śródmieście. Zakład Główny, zajmujący powierzchnię ponad 240000 metrów kwadratowych, znajdował się w obrębie ówczesnych ulic Olimpijskiej, Róży Luksemburg, Markiefki, Kopalnianej i al. Walentego Roździeńskiego. Zakład był ochraniany przez Straż Przemysłową, zakładową jednostkę ORMO oraz tak zwany pluton polityczno-obronny.

\footnotetext{
9150 lat kopalni wegla kamiennego „Katowice”, Katowice 1973, s. 16; H. Maroszek, Kopalni Wegla Kamiennego „Katowice” 1823-1988, Katowice 1988, s. 14.

${ }^{10}$ G. Grzegorek, A. Frużyński, P. Rygus, Kopalnie i huty Katowic, Katowice 2017, s. 47.

11 150 lat kopalni węgla kamiennego „,Katowice”..., s. 43.

${ }^{12}$ G. Grzegorek, A. Frużyński, P. Rygus, op. cit., s. 44, 49-50.

${ }^{13}$ R.W. Borowy, op. cit., s. 388-390.
} 
W kopalni znajdowały się dwa szyby główne - „Gwarek” i „Warszawa II” oraz dwa szyby pomocnicze - „Bartosz” i „Warszawa I”. Szyb „Gwarek” stanowił jedyne bezpośrednie połączenie do najniższego poziomu wydobywczego znajdującego się na poziomie 630 metrów. Służył on do wydobycia węgla $\mathrm{z}$ tego poziomu, regularnych zjazdów i wyjazdów załogi, wentylacji oraz opuszczania materiałów. Przez ten szyb w ciągu doby wydobywano ponad 3800 ton węgla. Szyb „Warszawa” był szybem dwuprzedziałowym o głębokości prawie 500 metrów. Przedział południowy „Warszawa II” służył do regularnej jazdy ludzi i wywozu na powierzchnię urobku. W ciągu doby przez ten szyb wydobywano około 2230 ton węgla. Natomiast pomocniczy przedział „Warszawa I” był wyposażony w dwie dwupiętrowe klatki i służył do okazyjnej jazdy pracowników na poziomy 200, 300, 400 i 500 metrów oraz do transportu materiałów, a także do wentylacji jako tak zwany szyb wdechowy. Szyb „Bartosz” był szybem pomocniczym i służył do transportu ludzi i materiałów na poziom 300 metrów $^{14}$.

$\mathrm{Na}$ terenie Zakładu Głównego znajdował się zakład przeróbki mechanicznej węgla (obejmujący płuczkę, sortownię i zwałowiska węgla), bocznica kolejowa (o całkowitej długości ponad 8,7 km, a użytkowej ok. 4,2 km) mogąca pomieścić 370 dwuosiowych wagonów, plac składowy kopalni oraz budynki administracyjne i obiekty socjalne. Na terenie placu znajdowały się dwa przeciwpożarowe zbiorniki wody. Poza Zakładem Głównym do kopalni należały szyb „Południowy”, znajdujący się przy ulicy Szybowcowej i Szyb „Bogucice”, zlokalizowany przy ulicy Wróblewskiego, około kilometr od Zakładu Głównego. Szyb „Bogucice” pełnił funkcję szybu wentylacyjnego, podsadzkowego i materiałowego, był także sporadycznie wykorzystywany do transportu ludzi na poziom 50, 100 i 300 metrów. W rejonie tego szybu zlokalizowano urządzenia podsadzkowe kopalni, obejmujące most rozładunkowy piaskarek, zbiornik szybowy piasku o pojemności 4000 metrów sześciennych, kruszarkę kamieni oraz trzy zbiorniki wody. Szyb „Południowy” znajdował się w niewielkiej odległości od lotniska Aeroklubu Śląskiego Katowice-Muchowiec. Szyb ten służył do wentylacji podziemia kopalni i dlatego wyposażony był w potężne wentylatory zasilane energią elektryczną z czterech stacji.

Pod koniec lat 80. średnie dobowe wydobycie węgla w kopalni wynosiło około 5000 ton, a w soboty 4900 ton. Ze względu na trudne warunki geologiczne roczne plany wydobycia węgla kształtowały się na poziomie około $1,5 \mathrm{mln}$ ton. Średnie zatrudnienie w kopalni oscylowało wokół 4000 osób, z czego robotników dołowych było około 2100 , robotników pracujących na powierzchni około 800 , pracowników umysłowych około 630, resztę zaś stanowili tak zwani pracownicy nieprzemysłowi. Stan zatrudnienia charakteryzował się jednak dużą fluktuacją. Średnio rocznie z kopalni odchodziło około 600 pracowników i podobną liczbę przyjmowano. Z pracy rezygnowały zwłaszcza osoby o niewielkim stażu pracy, a także odchodzący na wcześniejszą emeryturę.

${ }^{14}$ Archiwum Instytutu Pamięci Narodowej, Oddział w Katowicach (dalej: IPN Ka) 030/414 (dalej: IPN Ka 030/414), Sprawa obiektowa (SO) „Carbon”, Ogólna charakterystyka obiektu, z 2 IV 1982 r., k. $10-11$. 
Od 2 do 4 września 1980 roku w KWK „Katowice” miał miejsce strajk, którego uczestnicy wyrażali poparcie dla robotników Wybrzeża oraz solidarność z górnikami Rybnickiego Zjednoczenia Przemysłu Węglowego. Wysunięto szereg postulatów natury socjalno-bytowej, żądano poprawy płacy, likwidacji systemu czterobrygadowego oraz zmian w kierownictwie kopalni. Strajk zakończył się 4 września po otrzymaniu informacji o podpisaniu dzień wcześniej w KWK „Manifest Lipcowy” przez Prezydium Międzyzakładowego Komitetu Strajkowego z rządem porozumienia w Jastrzębiu Zdroju. Po zakończeniu strajku Zakładowy Komitet Strajkowy przekształcił się w Zakładową Komisję Robotniczą (ZKR). Jej przewodniczącym został Bolesław Sojka, zastępcą - Józef Waliczek, członkiem - Aleksander Filipek, a Jerzy Restel - łącznikiem ZKR z MKS w Jastrzębiu ${ }^{15}$. We wrześniu 1980 roku na terenie kopalni zaczął działać NSZZ „Solidarność” KWK „Katowice”. Do końca 1980 roku należało do niego około $80 \%$ załogi $^{16}$. Kopalnia stała się miejscem częstych spotkań ZKR-ów śląskich kopalń oraz Sekcji Górniczej Krajowej Komisji Koordynacyjnej z udziałem Lecha Wałęsy. Jednym z założycieli Związku w kopalni został Sojka pełniący do stycznia 1981 roku funkcję przewodniczącego. Po styczniowych wyborach został członkiem Komisji Zakładowej NSZZ „Solidarność” i Sekcji Węglowej Krajowej Komisji Koordynacyjnej NSZZ „Solidarność” ${ }^{17}$. Natomiast przewodniczącym ZKR NSZZ „Solidarność” przy KWK „Katowice” został Aleksander Filipek ${ }^{18}$.

Po delegalizacji NSZZ „Solidarność” do reżimowego Niezależnego Związku Zawodowego Pracowników KWK „Katowice” zapisało się około 2700 osób. Natomiast na przełomie 1988 i 1989 roku, na ponad 4000 zatrudnionych, do związku należało około 2500 pracowników i 700 emerytów. Jego przewodniczącym został Jan Zagajewski. Związek ten, działający w porozumieniu z dyrekcją i organizacją partyjną, zajmował się głównie przydzielaniem wczasów, zapomóg i innymi sprawami socjalnymi. W kopalni działała również Rada Pracownicza, na której czele stał Janusz Hopek, były działacz NSZZ „Solidarność” w latach 1980-1981, a jego zastępcą był Kazimierz Jarząbek, były działacz branżowych związków zawodowych. Liczba członków PZPR wahała się pomiędzy 550 a 600 pracowników, co stanowiło niecałe $14 \%$ załogi $^{19}$.

Pod koniec lat 80. poważnie pogorszyła się sytuacja ekonomiczna zakładu. Było to rezultatem prowadzenia prac $\mathrm{w}$ trudnych pokładach geologicznych oraz wydobycia węgla pod zabudową miasta. Szybko też postępowało wyczerpywanie się złóż węglowych. Pogarszał się stan nastrojów wśród załogi, co było spowodowane coraz trudniejszymi warunkami bytowymi, a zwłaszcza rosnącymi cenami i brakiem

${ }^{15}$ IPN Ka 036/1739, Sprawa operacyjnego sprawdzenia „Gosia” (dalej: IPN Ka 036/1739), Meldunek operacyjny z 9 IX 1980 r., k. 19; ibidem, Meldunek operacyjny z 11 II 1981 r., k. 151.

${ }_{16}$ Ibidem, Meldunek operacyjny z 11 II 1981 r., k. 151-153.

${ }^{17}$ IPN Ka 043/1017, Kwestionariusz ewidencyjny „Beta” (dalej: IPN Ka 043/1017), Notatka służbowa z 2 I 1982 r. i 6 I 1982 r., k. 12-14.

${ }^{18}$ IPN Ka 048/1210, Sprawa operacyjnego rozpoznania „Alfa” (dalej: IPN Ka 048/1210), Notatka służbowa z 28 IV 1984 r., k. 139.

${ }_{19}$ IPN Ka 030/414, Analiza i ocena stanu bezpieczeństwa w KWK „Katowice” za 1987 r., z 29 XII 1987, k. 20. 
podwyżek płac. Jednym z widocznych skutków tej sytuacji była pogorszająca się dyscyplina pracy. Jednocześnie, wobec rozpoczętych obrad okrągłego stołu, rosły oczekiwania na pozytywne zmiany gospodarcze i społeczne oraz na reaktywowanie NSZZ „Solidarność”.

\section{DZIAŁANIA SŁUŻBY BEZPIECZEŃSTWA WOBEC KWK „KATOWICE”}

Przez cały okres PRL-u funkcjonariusze UB/SB skrupulatnie odnotowywali wszelkie zdarzenia w zakładach pracy w całej Polsce. Rejestrowano zarówno przypadki bezpośrednio odnoszące się do problemów gospodarczych, jak i polityczno-społecznych, chociaż niejednokrotnie trudno było jeden typ oddzielić od drugiego. Działania te zintensyfikowano po 1980 roku, co wiązało się z powstaniem NSZZ „Solidarność”, wprowadzeniem stanu wojennego, a następnie działalnością opozycyjną podziemnej Solidarności. Ze względu na znaczenie górnictwa węglowego w systemie gospodarczym działania te były wyjątkowo skrupulatnie prowadzone na terenie śląskich kopalń.

Aktywne działania podjęte w KWK „Katowice” przez funkcjonariuszy SB uniemożliwiły przeprowadzenie akcji strajkowej w momencie wprowadzenia stanu wojennego. Niemniej jednak władze uważały, że - pomimo delegalizacji Solidarności w kopalni będą podejmowane działania mające na celu reaktywowanie Związku.

Kontrolą operacyjną kopalni zajmował się przede wszystkim utworzony na przełomie 1981-1982 roku V Wydział Miejskiego Urzędu Spraw Wewnętrznych (MUSW) w Katowicach, w którego kompetencjach znajdowała się „ochrona sektora górnictwa i energetyki" ${ }^{20}$. Według sprawozdania z końca 1987 roku wydział wykorzystywał 17 tajnych współpracowników (TW) ulokowanych w różnych punktach zakładu, zarówno na powierzchni, jak i pod ziemią oraz 10 kontaktów służbowych (KS). Wśród KS znajdowały się osoby zatrudnione w dyrekcji, straży przemysłowej, dziale wojskowym, dziale BHP, komitecie zakładowym partii i związkach zawodowych. Byli to zarówno pracownicy dozoru, jak i robotnicy. Ponadto swoich współpracowników miały inne wydziały SB i MO. W ocenie funkcjonariuszy SB liczba współpracowników była niewystarczająca dla zapewniania właściwej kontroli przedsiębiorstwa. Jak stwierdził starszy inspektor Wydziału V SB MUSW w Katowicach kapitan Stanisław Cecha:

Posiadane źródła informacji nie są w pełni wystarczające i istnieje konieczność bieżącego pozyskiwania nowych, wartościowych źródeł. Jednocześnie należy eliminować słabe źródła, unikające spotkań i przekazujące informacje o małej wartości operacyjnej. Posiadane osobowe źródła informacji powinny zapewnić stały, systematyczny dopływ informacji o wrogiej

${ }^{20}$ R. Terlecki, Miecz i tarcza komunizmu. Historia aparatu bezpieczeństwa w Polsce 1944-1990, Kraków 2007, s. 361; F. Musiał, Podręcznik bezpieki. Teoria pracy operacyjnej Stużby Bezpieczeństwa w świetle wydawnictw resortowych Ministerstwa Spraw Wewnętrznych PRL (1970-1989), Kraków 2007, s. 39-55. 
działalności ewentualnych grup antysocjalistycznych i antypaństwowych, jak również o działalności nielegalnych lub zamierzających się tworzyć struktur związkowych ${ }^{21}$.

W kwietniu 1982 roku katowicka SB przejęła od Wojskowej Służby Wewnętrznej 2. Brandenburskiej Dywizji Lotnictwa Szturmowo-Rozpoznawczego w Pile i zarejestrowała jako tajnego współpracownika o pseudonimie „Pilot”22 (nr rej. 49392) pracownika dozoru z oddziału wentylacji. Do końca 1987 roku przekazał zaledwie pięć ustnych informacji, w związku z tym został wytypowany do wyeliminowania z sieci OZI. TW „Karol”23 (nr rej. 53885) został pozyskany do współpracy w sierpniu 1983 roku, był pracownikiem dozoru w oddziałach wydobywczych i dostarczał informacji na piśmie. Wynagradzano go finansowo. TW „Jurek”24 (nr rej. 46289) przystąpił do współpracy „na zasadach dobrowolności” w listopadzie 1982 roku. Także był pracownikiem dozoru, a w okresie działalności NSZZ „Solidarność” jej aktywnym członkiem. TW „Kornakowicz”25 (nr rej. 53193) przystąpił do współpracy z SB w czerwcu 1983 roku. Składał pisemne informacje dotyczące nieprawidłowości $\mathrm{w}$ gospodarce materiałami strzałowymi, ale również wypowiadanych przez kolegów komentarzy odnoszących się do bieżących wydarzeń politycznych. W marcu 1984 roku współpracę z funkcjonariuszami bezpieki podjął TW „Grab” (nr rej. 51290). Był pracownikiem dozoru w oddziale dołowym. Nie był jednak chętny do współpracy, dlatego też rozważano możliwość jego eliminacji z sieci OZI. We wrześniu 1984 roku, na zasadzie dobrowolności, pozyskano do współpracy TW „Zyga”26 (nr rej. 50981). Był pracownikiem dołowym kopalni. Ze względu na słabe powiązania z funkcjonariuszami traktowano go jako „źródło sygnalne”. Ustnych, chociaż niesystematycznych informacji udzielał pracownik działu BHP, TW „Sylwek”27 (nr rej. 53257). Zarejestrowano go we wrześniu 1984 roku. Również był traktowany jako „źródło sygnalne”. Przodowy górnik, a jednocześnie tajny współpracownik o pseudonimie „Kuba”28 (nr rej. 58016), rozpoczął współpracę z SB w marcu 1985 roku. Wykorzystywano go w prowadzeniu Sprawy Obiektowej (SO) „Carbon” oraz w kwestionariuszu ewidencyjnym (KE) o kryptonimie „Beta”. W maju 1985 roku

${ }^{21}$ IPN Ka 030/414, Analiza i ocena stanu bezpieczeństwa w KWK „Katowice” za 1987 r., z 29 XII 1987, k. 23-24.

${ }^{22}$ IPN Ka 0055/1559, t. 1-2, Teczka personalna i teczka pracy tajnego współpracownika pseudonim „Pilot”.

${ }^{23}$ IPN Ka 00250/95, t. 1-3, Teczka personalna i teczka pracy tajnego współpracownika pseudonim „Karol”.

${ }^{24}$ IPN Ka 0055/1371, t. 1-2, Teczka personalna i teczka pracy tajnego współpracownika pseudonim „Jurek”.

${ }^{25}$ IPN Ka 0055/1491, t. 1-2, Teczka personalna i teczka pracy tajnego współpracownika pseudonim „Kornakowicz”.

${ }^{26}$ IPN Ka 0055/1492, t. 1-2, Teczka personalna i teczka pracy tajnego współpracownika pseudonim „Zyga”.

${ }^{27}$ IPN Ka 0062/803, t. 1-2, Teczka personalna i teczka pracy tajnego współpracownika pseudonim „Sylwek".

${ }^{28}$ IPN Ka 00233/3990, Teczka personalna; IPN Ka 00250/148 t. 1-2, Teczka personalna i teczka pracy tajnego współpracownika pseudonim „Kuba”. 
do współpracy pozyskano TW „Krzyś”29 (nr rej. 58343), pracującego w oddziale pomocniczym pod ziemią. Wykorzystywano go przy opracowywaniu materiałów dotyczących sprawy operacyjnego sprawdzenia (SOS) „Neptun” oraz przy inwigilacji domów górnika. Następnie przeniósł się do pracy w województwie kieleckim. Jeden z pracowników dozoru mający dostęp do wszystkich rejonów kopalni został zarejestrowany w marcu 1986 roku jako TW „Piotrek”30 (nr rej. 60767). Odbywał systematyczne spotkania z funkcjonariuszami SB i dostarczał informacji dotyczących zwłaszcza związków zawodowych oraz rady pracowniczej. Był niezwykle przydatny w prowadzonej SO „Carbon” i KE „Beta”. W maju 1986 roku zarejestrowano pracownika dozoru oddziału mechanicznego. Przekazywał głównie informacje ustne jako TW „Górnik”31 (nr rej. 55450). Z kolei w czerwcu 1986 roku współpracę podjął pracownik dozoru pracujący w oddziale pod ziemią. Przyjął pseudonim „Borys”32 (nr rej. 61826). W SOS o kryptonimie „Jowisz” i „Wulkan” oraz SO „Carbon” był wykorzystywany TW „Felek” (nr rej. 62707) zarejestrowany w październiku 1986 roku. Był pracownikiem dozoru w oddziale wydobywczym. TW „Adaś”33 (nr rej. 61844), fizyczny pracownik dołowy, był wykorzystywany przy prowadzeniu SOS „Wulkan” i SO „Carbon”. Został pozyskany w listopadzie 1986 roku. W dokumentacji TW „Francek”"34 (nr rej. 63629) zapisano: „pozyskany w dniu 18.03.1987 roku na zasadzie dobrowolności, wykorzystując jego zainteresowania materialne" ${ }^{35}$. Był pracownikiem dozoru w oddziale wydobywczym, wykorzystywanym przy prowadzeniu SOS „Jowisz” i SO „Carbon”. Przegląd sytuacji w całej kopalni miał jej dyspozytor zarejestrowany w czerwcu 1987 roku jako TW „Kazek”36 (nr rej. 64317). Wykorzystywano go przy prowadzeniu spraw operacyjnego sprawdzenia o kryptonimie „Saturn” i „Delta” oraz SO „Carbon”. Możliwość docierania do wszystkich miejsc na terenie zakładu miał pracownik działu BHP, zarejestrowany we wrześniu 1987 roku jako TW „Kornel”37 (nr rej. 63889). Sporządzone przez niego donosy wykorzystywano w SOS „Saturn” i SO „Carbon”. W sumie w 1987 roku funkcjonariusze

${ }^{29}$ IPN Ka 00250/147, Teczka personalna; IPN Ka 0055/1435, t. 1-2, Teczka personalna i teczka pracy tajnego współpracownika pseudonim „Krzyś””.

${ }^{30}$ IPN Ka 0055/1469, t. 1-2, Teczka personalna i teczka pracy tajnego współpracownika pseudonim „Piotrek”.

${ }^{31}$ IPN Ka 0055/1563, t. 1-2, Teczka personalna i teczka pracy tajnego współpracownika pseudonim „Górnik".

${ }^{32}$ IPN Ka 00233/3985, Teczka personalna; IPN Ka 0055/1506, t. 1-2, Teczka personalna i teczka pracy tajnego współpracownika pseudonim „Borys”.

${ }_{33}$ IPN Ka 0055/1493, Teczka personalna; IPN Ka 00233/4000, t. 1-2, Teczka personalna i teczka pracy tajnego współpracownika pseudonim „Adaś”.

${ }^{34}$ IPN Ka 0055/1327, t. 1-2, Teczka personalna i teczka pracy tajnego współpracownika pseudonim „Francek”.

${ }^{35}$ IPN Ka 030/414, Ocena i rozmieszczenie posiadanych tajnych współpracowników, k. 27.

${ }^{36}$ IPN Ka 0055/1434, t. 1-2, Teczka personalna i teczka pracy tajnego współpracownika pseudonim „Kazek”.

${ }^{37}$ IPN Ka 0055/1558, t. 1-2, Teczka personalna i teczka pracy tajnego współpracownika pseudonim „Kornel”. 
V Wydziału MUSW odbyli 158 spotkań z tajnymi współpracownikami, podczas których zebrali 96 informacji pisemnych i 62 ustne $^{38}$.

Pod koniec kwietnia 1982 roku pułkownik Józef Sasin, dyrektor Departamentu V MSW, zatwierdził wniosek zastępcy komendanta wojewódzkiego w Katowicach do spraw Służby Bezpieczeństwa, pułkownika Henryka Sikory o wszczęciu sprawy obiektowej (SO) o kryptonimie „Carbon” ${ }^{39}$. Sprawę założono 2 kwietnia pod numerem KA-49933. Jak napisano we wniosku, celem sprawy była:

Ochrona operacyjna obiektu oraz ujawnianie, likwidowanie i zapobieganie źródłom zagrożeń, ich skutkom w zakresie działalności antypaństwowej i antysocjalistycznej, konfliktów i negatywnych nastrojów wśród załogi, sabotażu i dywersji, nieprawidłowości w funkcjonowaniu zakładu z przyczyn subiektywnych, nieprawidłowości w obrocie środkami strzelniczymi ${ }^{40}$.

Wcześniej nie było osobnej sprawy obiektowej założonej na tę kopalnię, a jej „operacyjna ochrona” była jednym z elementów inwigilacji Katowickiego Zjednoczenia Przemysłu Węglowego. W ramach prowadzonej SO „Carbon” kontrolowano także działalność byłych członków kopalnianej Solidarności.

W latach 80. SB prowadziła na terenie KWK „Katowice” kilka niezależnych od siebie spraw operacyjnych i kwestionariuszy ewidencyjnych dotyczących zarówno kwestii politycznych, jak i przestępstw gospodarczych ${ }^{41}$. Wśród pracowników kopalni internowanych $\mathrm{w}$ chwili wprowadzenia stanu wojennego znalazł się wiceprzewodniczący ZKR NSZZ „Solidarność” Bolesław Sojka, zwolniony z ośrodka odosobnienia dopiero po upływie roku. Po powrocie Bolesław Sojka podjął pracę w kopalni. Przeprowadzono z nim rozmowę ostrzegawczą, w trakcie której oświadczył, że nie będzie podejmował działalności niezgodnej z przepisami stanu wojenne$\mathrm{go}^{42}$. Już w marcu 1983 roku założono jednak na niego kwestionariusz ewidencyjny o kryptonimie „Beta” (nr rej. 46288), gdyż, jak zapisano: „W sprzyjających okolicznościach może podjąć wrogą działalność, niezgodną z obowiązującymi przepisami prawnymi" ${ }^{43}$.

${ }^{38}$ IPN Ka 030/414, Analiza i ocena stanu bezpieczeństwa w KWK „Katowice” za 1987 r., z 29 XII 1987, k. 24-26.

${ }^{39}$ H. Sikora rozpoczął swoją karierę w organach bezpieczeństwa w marcu 1949 r. jako starszy referent Sekcji VIII Wydziału IV WUBP w Katowicach. W marcu 1977 r. został zastępcą komendanta wojewódzkiego w Katowicach ds. SB KW MO, a w sierpniu 1983 r. zastępcą szefa ds. SB WUSW Katowice, por. Sikora Henryk, Kadra bezpieki 1945-1990. Obsada stanowisk kierowniczych aparatu bezpieczeństwa w województwach śląskim/katowickim, bielskich i częstochowskim, wstęp i red. W. Dubiański, A. Dziuba, A. Dziurok, Katowice 2009, s. 445-446.

${ }^{40}$ IPN Ka 030/414, Wniosek o wszczęciu sprawy obiektowej o kryptonimie „Carbon”, z 4 IV 1982 r., k. 8; IPN Ka 030/414, Analiza i ocena stanu bezpieczeństwa w KWK „Katowice” za 1987 r., z 29 XII 1987, k. 20.

${ }^{41}$ Sprawie inwigilacji NSZZ „Solidarność” i jego działaczy w KWK „Katowice” autor poświęcił artykuł zamieszczony w przygotowywanej do druku pracy zbiorowej zatytułowanej: Po stronie prawdy. Księga dedykowana Zofii i Zbigniewowi Romaszewskim, red. C. Kuta, M. Krzysztofiński. Publikacja pracy w Wydawnictwie Instytutu Pamięci Narodowej zaplanowana została na $2020 \mathrm{r}$.

42 IPN Ka 230/2998, t. 2, Kwestionariusz ewidencyjny „Beta” (!) (dalej: IPN Ka 230/2998), Wyciąg z notatki ze spotkania z TW ps.[edonim] Jurek z 7 III 1983 r., k. 21.

${ }^{43}$ IPN Ka 043/1017, Wniosek o założenie kwestionariusza ewidencyjnego z 24 III 1983 r., k. 29-30. 
Problemem, z którym zmagali się funkcjonariusze SB w pierwszej połowie lat 80., były nielegalne ulotki rozprowadzane albo w samej kopalni, albo też w jej bezpośrednim sąsiedztwie. Pomimo wprowadzenia stanu wojennego grupa osób związana z KWK „Katowice” nie zaprzestała działalności w zdelegalizowanym przez komunistów Związku i podjęła aktywność poligraficzną oraz kolportażową. Od lutego 1982 roku do lipca 1983 roku drukowała i dystrybuowała nielegalne ulotki oraz wydawnictwa „Gottwaldowiec” i „Regionalny Informator Solidarności Śląsko-Dąbrowskiej" ${ }^{44}$. Gdy w połowie lipca 1982 roku ujawniono ulotki sygnowane stemplem Solidarności, „szkalujące WRON” i nawołujące do uczczenia górników zamordowanych w kopalni „Wujek” poprzez milczące spotkanie pod krzyżem przy kopalni „Wujek”, funkcjonariusze WUSW w Katowicach założyli SOS o kryptonimie „Alfa” ( nr KA 50299), przekwalifikowaną 24 lipca na sprawę operacyjnego rozpoznania $(\mathrm{SOR})^{45}$. Jedną z osób podejrzanych o możliwość prowadzenia „wrogiej” działalności był Paweł Głowacki. Dlatego też w styczniu 1986 roku założono na niego kwestionariusz ewidencyjny o kryptonimie „Jowisz” (nr 60589), którego celem było „ustalenie zakresu wpływu na załogę, rodzinę i środowisko” oraz „neutralizacja podejmowanych przez figuranta negatywnych działań w miejscu zatrudnienia i zamieszkania" ${ }^{46}$.

W ramach prowadzonej SO „Carbon” do końca lat 80. kontrolowano byłych członków kopalnianej Solidarności. W KWK „Katowice” wciąż pracował były przewodniczący ZKR NSZZ „Solidarność” Aleksander Filipek oraz członkowie prezydium - Stefan Kordzikowski i Helmut Hetmański. Inwigilowano Stefana Widerę i Henryka Siewiorka, skazanych za kolportaż ulotek, a następnie ,amnestionowanych". Jeszcze w lutym 1989 roku w WUSW w Katowicach zarejestrowano sprawę operacyjnego rozpracowania o kryptonimie „Brzoza” (nr rej. KA-67884) ${ }^{47}$. Działania te były związane z podjęciem przez jedenastu pracowników KWK „Katowice” uchwały o utworzeniu Niezależnego Związku Zawodowego „Solidarność” Pracowników KWK „Katowice”. W tym czasie w Warszawie toczyły się już obrady „okrągłego stołu”.

${ }^{44}$ Tytuł przyjęto od nazwy KWK „Gottwald”.

${ }_{45}$ IPN Ka 048/1210, Komunikat z obserwacji ob. PRL Płoski Franciszek, z. 15 X 1982 r., k. 67-68; IPN Ka 048/1210, Notatka służbowa z 11 IV 1984 r., k. 147; IPN Ka 048/1210, Informacja z 9 VI 1984 r., k. $148-149$.

${ }^{46}$ IPN Ka 048/633, KE „Jowisz”, Wniosek o założenie kwestionariusza ewidencyjnego, z 17 I 1986 r., k. 4; IPN Ka 030/414, Analiza kwestionariusza ewidencyjnego krypt.[onim] „Jowisz” z 31 VIII 1989 r., k. 45.

${ }^{47}$ IPN Ka 030/414, [Informacja] dotycząca KWK „Katowice”, z 6 II 1989 r., k. 17-18; IPN Ka 048/576, SOR „Brzoza”, Plan przedsięwzięć operacyjnych do sprawy operacyjnego rozpracowania krypt.[onim] „Brzoza” z 7 II 1989 r., k. 13. 


\section{SB WOBEC „ZAGROŻEŃ” GOSPODARCZYCH W KWK „KATOWICE”}

Katowicka Służba Bezpieczeństwa opracowała „prognozę zagrożeń” mogących wystąpić na terenie kopalni „Katowice”. Oprócz zdarzeń natury politycznej wymieniono także „zagrożenia” dotyczące spraw gospodarczych, związanych z funkcjonowaniem kopalni, do których zaliczono:

[...] niewłaściwą gospodarkę materiałami strzałowymi połączoną z ich kradzieżą celem wykorzystania ich przez elementy wrogie; powstawanie sytuacji konfliktowych wśród załogi w związku z podwyżkami cen, brakami w zaopatrzeniu w podstawowe artykuły przemysłowe i żywnościowe; fakty marnotrawstwa i niegospodarności; powstawanie faktów mających znamiona dywersji i sabotażu; nieprzestrzeganie przepisów BHP, co stwarza możliwość powstawania wypadków nadzwyczajnych, nieprzestrzeganie regulaminu pracy, zwiększanie czasu pracy tzw. „rolki”48; ukrywanie i niezgłaszanie wypadków przy pracy i innych zdarzeń mających istotne znaczenie w procesie wydobycia i prawidłowego funkcjonowania przedsiębiorstwa; nieprzestrzeganie tajemnicy państwowej i służbowej; próby przenikania osób z krajów kapitalistycznych na teren kopalni i do załogi celem negatywnego oddziaływania na ich postawy; wyjazdy obywateli polskich do krajów kapitalistycznych w ramach wycieczek, odwiedzin i odmowy powrotu do kraju; próby przenikania przedstawicieli firm kapitalistycznych do załogi celem uzyskiwania nowych rozwiązań technologicznych lub umożliwiania wprowadzania do kopalń przestarzałych rozwiązań zachodnich; próby zakłóceń ładu i porządku, kolportaż ulotek i wrogich haseł w okresie świąt państwowych - 1, 3, 9 maja, 22 lipca, jak również rocznic 31 VIII, 10-11 XI, 13-16 XII ${ }^{49}$.

Funkcjonariusze SB sporządzili wykaz obiektów podlegających szczególnemu zabezpieczeniu. W Zakładzie Głównym, w czterech budynkach administracyjnych oznaczonych kolejno literami od A do D, wyszczególniono takie obiekty jak: magazyny broni Straży Przemysłowej i Ligi Obrony Kraju, magazyn obrony cywilnej, główną rozdzielnię złącz teletechnicznych, pomieszczenie urządzeń teleksowych,

${ }^{48}$ Załamanie się sytuacji gospodarczej w PRL na początku lat 80 . XX w. skłoniło władze do wprowadzenia pracy w kopalniach $\mathrm{w}$ dodatkowym wymiarze czasu, za specjalnym wynagrodzeniem. Służyła temu uchwała rządu nr 199/81 przyjęta 11 IX 1981 r. Mówiła o zwiększeniu zatrudnienia w górnictwie, zmianowości pracy na przodkach eksploatacyjnych i przy robotach przygotowawczych oraz o lepszym zaspokajaniu zapotrzebowania kopalń na maszyny i urządzenia górnicze, sprzęt pomocniczy oraz części zamienne. Oprócz pracowników wykonujących prace związane z wydobyciem węgla, wykonywaniem robót remontowo-konserwacyjnych, a także pracowników związanych ze stałą obsługą urządzeń, wyższe wynagrodzenie mieli otrzymać także pracownicy wchodzący w skład grupy przemysłowej zajmujący się sprzątaniem pomieszczeń, transportem i sprzedażą owoców, obsługą tuczarni, obsługą wycieczek domów wczasowych, obsługą obozów, obsługą kolonii, obsługą domów górnika, obsługą domów kultury, obsługą akcji ziemniaczanej, obsługą wywozu węgla deputatowego oraz pracami biurowymi. Większość górników odrzucała tę formę zapłaty za pracę żądając wyższej pensji za pracę w dni robocze. Uchwałę potępili przedstawiciele komisji zakładowych NSZZ „Solidarność” kopalń węgla, surowców chemicznych, surowców mineralnych i rud oraz zakładów przemysłu górniczego zebranych 16 IX w kopalni „Katowice”. Por. Encyklopedia Solidarności, R. Miłoch, Uchwała Rady Ministrów nr 199/81, http:// www.encysol.pl/wiki/Uchwa\%C5\%82a_Rady_Ministr\%C3\%B3w_nr_199/81 (dostęp: 15.05.2020).

${ }^{49}$ IPN Ka 030/414, Analiza i ocena stanu bezpieczeństwa w KWK „Katowice” za 1987 r., z 29 XII 1987, k. 28-29. 
stację sejsmograficzną, pomieszczenie urządzeń liczących działu finansowo-księgowego, urządzenia kserograficzne, radiowęzeł, ale także kasę zakładową, kasę zapomogowo-pożyczkową, ajencję PKO, kancelarię ogólną, archiwum działu zatrudnienia, archiwum zakładowe, kancelarię, tajną kancelarię, centralę telefoniczną i szereg innych pomieszczeń. Ponadto na liście znalazł się magazyn olejów i smarów, gazów technicznych oraz kotłownia.

Osobno opisano newralgiczne punkty, do których na terenie Zakładu Głównego zaliczono: maszyny wyciągowe szybów „Warszawa I”, „Warszawa II”, „Gwarek” i „Bartosz”, nadszybia szybów „Warszawa II” i „Bartosz”, kilka stacji transformatorowych i rozdzielnie energii elektrycznej, budynki pompowni i wieży ciśnień, dystrybutory paliwa, zajezdnię lokomotyw, laboratorium chemiczne oraz zakład mechanicznej przeróbki węgla. Na szybie „Bogucice” za takie miejsca uznano nadszybie, maszynę wyciągową, rozdzielnię, wentylator oraz most wyładowczy piasku. Podobnie na szybie „Południowym” wskazano na maszynę wyciągową wraz z jej rozdzielnią, trzy wentylatory oraz budynek sprężarek i magazyn oleju ${ }^{50}$.

Oprócz działań profilaktycznych i represyjnych mających na celu ograniczenie lub całkowitą likwidację działalności nielegalnych struktur związkowych funkcjonariusze SB zwracali również uwagę na nieprawidłowości w gospodarce maszynami i urządzeniami, na niegospodarność, marnotrawstwo, fałszowanie danych odnośnie do wielkości wydobycia oraz wypadków w pracy. Przykładowo tylko w 1987 roku odnotowano 136 wypadków, w tym jeden śmiertelny. Ujawniono 152 przypadki wykroczeń związanych ze spożyciem alkoholu, w rezultacie czego dyscyplinarnie zwolniono 5 osób. Szczególną uwagę zwracano na gospodarkę materiałami strzałowymi.

Sprawę operacyjnego sprawdzenia o kryptonimie „Gama” (nr rej. KA-51985) założono 28 lutego 1983 roku, a zakończono dopiero dwa lata później ${ }^{51}$. Przyczyną jej rozpoczęcia była informacja uzyskana od TW o pseudonimie „Henio” odnosząca się do systematycznych przerw w zjeździe pracowników szybem „Warszawa II”. Z drugiej zaś strony uwagę funkcjonariuszy SB zwróciła notatka zamieszczona w Biuletynie „Ku Wolnej Polsce” nr 3/83 z 10 stycznia 1983 roku, wydawanym przez MKR NSZZ „Solidarność” Regionu Śląsko-Dąbrowskiego. Notatka ta zawierała następującą informację: „20.12.1982 roku w KWK «Katowice» w wyniku sprawnej akcji unieruchomiono szyb «Warszawa II» przecinając kabel zasilający w energię. Zostawiono narzędzia, aby nie było podejrzeń, że to usterki techniczne" 52 . Funkcjonariusze SB postanowili sprawdzić stan faktyczny i ewentualnie ustalić przyczynę awarii oraz winnych zaistniałej sytuacji. Sprawa była niezwykle ważna, gdyż zdarzenie miało miejsce w czasie wciąż jeszcze obowiązującego stanu wojennego. Dochodzenie prowadzone przez Wydział V MUSW w Katowicach komplikowała informacja, że sprawcą zaistniałej awarii był Roman Lewek, działacz podziemnej

${ }^{50}$ IPN Ka 030/414, Sprawa obiektowa (SO) „Carbon”, Ogólna charakterystyka obiektu, z 2 IV 1982 r., k. 10-16.

${ }^{51}$ IPN Ka 048/1860, SOS „Gama” (dalej: IPN Ka 048/1860), Wniosek o zakończenie sprawy operacyjnego sprawdzenia krypt.[onim] „Gama”, z 31 I 1985 r., k. 8.

${ }^{52}$ IPN Ka 048/1860, Wniosek o wszczęcie sprawy operacyjnego sprawdzenia krypt. „Gama”, z 28 II 1983 r., k. 1. 
Solidarności, pracownik kopalni, który zmarł na początku marca 1983 roku. Wkrótce okazało się, że trwająca pięć minut przerwa w pracy maszyny wyciągowej szybu była spowodowana przeciążeniem sieci energetycznej, a nie celowym działaniem. Wydarzenie to jednak zostało wykorzystane przez działaczy Solidarności do działań propagandowych ${ }^{53}$. Sprawa, formalnie prowadzona przez dwa lata, posłużyła wszakże funkcjonariuszom SB do sporządzenia wykazu wszystkich przerw w pracy szybów „Warszawa II”, „Bartosz” i „Gwarek” oraz bardzo szczegółowej analizy zasad funkcjonowania szybów i kontroli ich stanu technicznego.

Pod koniec stycznia 1986 roku doszło do ośmiogodzinnego zatrzymania pracy szybu „Gwarek” w KWK „Katowice”, spowodowanego jego zalaniem na poziomie 500. Dopiero trzy tygodnie później, 18 lutego, funkcjonariusze katowickiej SB założyli jednak sprawę operacyjnego sprawdzenia o kryptonimie „Mars” (nr rej. KA-60796). Jej celem było ustalenie wszystkich okoliczności zdarzenia, strat jakie spowodowało, motywów działania sprawców, wskazania winnych oraz „,neutralizacja w przyszłości podobnych zagrożeń" ${ }^{54}$. Plan działań operacyjnych opracowany przez kapitana Cechę przewidywał aż jedenaście punktów realizowanych w ciągu dwóch miesięcy. Zasadniczo były to polecenia przeprowadzenia rozmów z pracownikami obsługi i nadzoru, ale w ostatnim punkcie planu zapisano:

W przypadku odstąpienia od wszczęcia postępowania przygotowawczego wytypować, opracować w charakterze kandydata na tw jednego z winnych zaistnienia zdarzenia, celem zapewnienia w przyszłości dopływu informacji z tego działu ${ }^{55}$.

Po przeprowadzeniu dochodzenia stwierdzono, że przyczyną zalania szybu było zatkanie osadników. Zdarzenie nie stanowiło zagrożenia dla funkcjonowania zakładu oraz nie spowodowało strat w wydobyciu węgla. Incydent ten nastąpił $\mathrm{z}$ winy pracowników, którzy niedokładnie kontrolowali stan osadników i niewłaściwie prowadzili dokumentację, a także pracowników dozoru, którzy tolerowali niedbałości przy obsłudze pompy. Ustalono winnych zaistniałej sytuacji. Było to trzech pracowników bezpośrednio odpowiedzialnych za obsługę pomp. Odpowiedzialnością obciążono także kierownika oddziału. Wszyscy zostali ukarani upomnieniem i pozbawieni premii za jeden miesiąc. Taka sama kara spotkała głównego mechanika do spraw urządzeń wyciągowych. Ponadto kierownictwo kopalni zostało zobowiązane do podjęcia działań zapobiegających powstawaniu podobnych sytuacji w przyszłości ${ }^{56}$.

Sprawa operacyjnego sprawdzenia (SOS) „Wulkan” o numerze rejestracyjnym 62419, została założona 8 września 1986 roku, w związku z informacją uzyskaną od KS „CJ” o zaginięciu na poziomie 630 metrów 3 kilogramów materiałów

${ }^{53}$ IPN Ka 048/1860, Analiza sprawy operacyjnego sprawdzenia krypt.[onim] „Gama”, z 31 I 1985 r., k. $14-14 \mathrm{v}$.

${ }^{54}$ IPN Ka 048/197, SOS „Mars” (dalej: IPN Ka 048/197), Wniosek o wszczęcie sprawy operacyjnego sprawdzenia krypt. „Mars”, z 19 II 1986 r., k. 8.

55 IPN Ka 048/197, Plan przedsięwzięć operacyjnych do sprawy operacyjnego sprawdzenia krypt. [onim] „Mars” z 24 II 1986 r., k. 21-22.

${ }^{56}$ IPN Ka 048/197, Analiza sprawy operacyjnego sprawdzenia krypt.[onim] „Mars”, z 21 VIII 1986 r., k. 76-78. 
wybuchowych oraz dwóch zapalników elektrycznych. Materiał ten znajdował się na stanie górnika strzałowego, Wojciecha Pączka, który miał go przekazać nadgórnikowi Andrzejowi Połowniakowi. Podjęte poszukiwania w Domu Górnika numer 4 nie doprowadziły do odnalezienia zaginionych materiałów. W wyniku podjętych działań zarzut kradzieży przedstawiono dwóm pracownikom oddziału G-III - Wojciechowi Pączkowi i Jerzemu Strzeleckiemu. Pierwszy z nich został skazany przez Sąd Rejonowy w Katowicach na jeden rok pozbawienia wolności w zawieszaniu na trzy lata oraz grzywnę w wysokości 100000 złotych. W kopalni pozbawiono go uprawnień strzałowego. Wobec drugiego prokuratura umorzyła postępowanie, chociaż ukarano go odebraniem premii. Ostatecznie uznano, że materiały nie zostały skradzione, lecz zagubione lub zniszczone na dole kopalni. Jednocześnie ustalono, że Pączek niezgodnie z przepisami, bez pokwitowania przekazywał materiały wybuchowe nadgórnikowi Połowniakowi i wykazywał w dzienniczku strzałowego całkowite zużycie materiałów, a przy tym przerabiał wcześniejsze zapisy. W sprawie wykorzystywano tajnych współpracowników o pseudonimach „Karol” i „Felek” oraz aż pięć kontaktów służbowych.

W związku z tą sprawą i z inspiracji SB w dzienniku „Trybuna Robotnicza” zamieszczono artykuł poświęcony nieprawidłowościom w gospodarce materiałami wybuchowymi w kopani „Katowice” i grożącymi z tego powodu skutkami prawnymi. Sprawę, w której łącznie złożono 8 meldunków, zamknięto 18 grudnia 1987 roku. Jednocześnie kontynuowano obserwację Pączka i Strzeleckiego w ramach SO „Carbon". Ponadto zalecono osobowym źródłom informacji wzmożenie kontroli nad prowadzonymi pracami strzelniczymi oraz ujawnianie osób posiadających materiały wybuchowe lub zamierzających je zdobyć, a także zwiększenie kontroli w domach górnika ${ }^{57}$.

Pod koniec sierpnia 1986 roku MUSW w Katowicach otrzymał informację o kradzieży dwóch lasek materiału wybuchowego (barbarytu) o wadze 400 gramów. W związku z tym zdarzeniem 19 września 1986 roku SB zarejestrowała do numeru 62548 SOS o kryptonimie „Neptun”. W wyniku podjętych działań operacyjnych przeszukano Dom Górnika numer 4. Dzięki temu i pomocy TW o pseudonimie „Krzyś” i KS „WE” ustalono, że materiał ten jest w posiadaniu Jerzego Brelskiego, zajmującego pokój numer 12. Badania przeprowadzone w Głównym Instytucie Górnictwa - Kopalnia Doświadczalna „Barbara” w Mikołowie potwierdziły pełną zdolność detonacyjną tego materiału. Dlatego też wydział śledczy WUSW w Katowicach wszczął dochodzenie, przedstawiając Brelskiemu zarzuty natury kryminalnej. Podejrzany został aresztowany i przyznał się do kradzieży, przy czym wyjaśnił, że materiałów chciał użyć do „wytrucia kretów”. Nie udało się ustalić, aby podejrzany zamierzał użyć materiałów wybuchowych „do wrogiej działalności”. W listopadzie 1986 roku wyrokiem Sądu Rejonowego w Katowicach Brelski został skazany na karę jednego roku więzienia w zawieszeniu na trzy lata i grzywnę w wysokości

${ }^{57}$ IPN Ka 030/414, Analiza i ocena stanu bezpieczeństwa w KWK „Katowice” za 1987 r., z 29 XII 1987, k. 22; Analiza sprawy operacyjnego sprawdzenia krypt.[onim] „Wulkan” z 15 XII 1987 r., k. 35-36. 
90000 złotych oraz podanie wyroku do wiadomości załogi kopalni. SOS zamknięto 16 grudnia 1987 roku, natomiast Brelski miał być nadal kontrolowany w ramach SO „Carbon”. Z inicjatywy funkcjonariuszy SB także i ta sprawa została opisana w lutym 1987 roku w dzienniku „Trybuna Robotnicza”58.

Z kolei SOS „Jowisz” (nr rejestracyjny 62720) założona została 15 października 1986 roku. Podstawą do jej wszczęcia była informacja od TW „Sylwek” o odnalezieniu na poziomie 630 metrów 4 kilogramów materiału wybuchowego, owiniętego folią i zakopanego w piasku podsadzkowym ${ }^{59}$. W wyniku prowadzonych działań operacyjnych ustalono, że instruktor strzałowy, Krystian Kierzek odnotował w dzienniku strzałowym zużycie 40 kilogramów barbarytu powietrznego, pomimo wykorzystania tylko 36 kilogramów ${ }^{60}$. Kierzek otrzymał jeszcze 6 kilogramów barbarytu od innego górnika strzałowego, Józefa Kopcia. Materiał ten także ukrył w piasku podsadzkowym, podczas gdy Kopeć odnotował ich zużycie. Co więcej, sztygar zmianowy, Edward Joneczek także wpisał do dzienników strzałowych obu górników wykorzystanie po 40 kilogramów barbarytu. Wszyscy trzej zostali objęci aktem oskarżenia. 25 lutego 1987 roku wyrokiem Sądu Rejonowego w Katowicach Kierzek został skazany na półtora roku więzienia oraz 150000 złotych grzywny, podczas gdy dwaj pozostali otrzymali po jednym roku pozbawienia wolności w zawieszeniu na trzy lata i po 100000 złotych grzywny. Wszystkich pozbawiono uprawnień strzałowych. Sprawę, w której sporządzono 9 meldunków operacyjnych, zakończono 18 grudnia 1987 roku. Zaangażowano do niej tajnych współpracowników o pseudonimach „Karol”, „Sylwek”, i „Felek” oraz 5 kontaktów służbowych. W sumie działania SB ujawniły wiele nieprawidłowości w gospodarce materiałami wybuchowymi oraz brak właściwego nadzoru w kopalniach Katowickiego Gwarectwa Węglowego ${ }^{61}$.

Sprawa operacyjnego sprawdzenia o kryptonimie „Saturn” ( $\mathrm{nr}$ rejestracyjny 65261) została założona 6 listopada 1987 roku po uzyskaniu informacji od KS „SZ” i TW „Kazek” o śmiertelnym wypadku na poziomie 630 metrów. Podczas prowadzonych 2 listopada prac związanych z kasztowaniem stropu ${ }^{62}$ bryła węgla uderzyła górnika przodowego, Stanisława Mazura. Prace te były wykonywane w zwiększonym wymiarze czasu. W wyniku podjętych działań ustalono, że przyczyną wypadku było niewłaściwe zabezpieczenie ociosu ścianowego w miejscu składowania drewna i kasztowania wyrw w stropie. Za winnego tych zaniedbań uznano sztygara Grzegorza Krupińskiego, któremu odebrano 100\% miesięcznej pensji. Ponadto, upomnienia otrzymali czterej pracownicy dozoru. Skutkiem tych wydarzeń było zawieszenie wykonywania prac w zwiększonym wymiarze czasu. Podczas działań operacyjnych

${ }^{58}$ IPN Ka 030/414, Analiza sprawy operacyjnego sprawdzenia krypt.[onim] „Neptun” z 14 XII 1987 r., k. 33-34.

${ }^{59}$ Piasek służący do zamulania wyrobisk.

${ }^{60}$ Barbaryt powietrzny to górniczy materiał wybuchowy, w którym oprócz dynamitu znajduje się chlorek sodu (35-45\%), dzięki czemu może być bezpiecznie używany w atmosferze zawierającej metan i pył węglowy.

${ }^{61}$ IPN Ka 030/414, Analiza sprawy operacyjnego sprawdzenia krypt.[onim] „Jowisz” z 14 XII 1987 r., k. 38-39.

${ }^{62}$ Kasztowanie, czyli podpieranie stropu wyrobiska, por. S. Gisman, Stownik górniczy, Katowice 1949, s. 100. 
korzystano z informacji dostarczanych przez tajnych współpracowników „Karol”, „Kazek” i „Kornel”, jak również z pomocy kontaktów służbowych ${ }^{63}$.

Kolejna sprawa operacyjnego sprawdzenia nosiła kryptonim „Delta”(nr rej. 63600) i została wszczęta pod koniec lutego 1987 roku. Jej założenie spowodowane było rosnącym niezadowoleniem wśród pracowników kopalni „Katowice” wynikającym z wprowadzenia, chociaż odpłatnej, to jednak w zwiększonym wymiarze czasu dodatkowej pracy, którą popularnie nazywano „rolkami”. Dyrekcja kopalni zdecydowała się na wprowadzenie tego systemu, gdyż w normalnym wymiarze szycht nie udawało się zrealizować zadań wydobywczych. Większość pracowników odnosiła się do tego rozwiązania $\mathrm{z}$ dużą niechęcią, a nawet odmawiała wykonywania pracy w tym systemie. Bardzo szybko okazało się, że przyjęte rozwiązanie nie tylko nie przynosiło zamierzonych efektów, ale również prowadziło do zwiększenia kosztów eksploatacji węgla, większej awaryjności maszyn, które nie były dostatecznie konserwowane, a co gorsza do zwiększenia liczby wypadków. Przyjęte rozwiązania spowodowały także narastanie sytuacji konfliktowych między górnikami a pracownikami dozoru. Pierwsi z nich otrzymywali około 1500 złotych dodatkowo za 2 godziny pracy, podczas gdy pracownicy dozoru znacznie więcej. W zbieraniu informacji na ten temat z funkcjonariuszami SB współpracowali agenci o pseudonimach „Karol” i „Kazek” oraz kontakty służbowe „KS” i „SZ”. Z obawy przed narastaniem niezadowolenia wśród załogi kopalni mogącego prowadzić do sytuacji strajkowych katowicka Służba Bezpieczeństwa podjęła rozmowy z kierownictwem kopalni, w wyniku których zaniechano tej formy pracy ${ }^{64}$.

\section{ZAKOŃCZENIE}

Znaczenie górnictwa węglowego dla gospodarki polskiej, duża koncentracja pracowników przemysłowych oraz skala sprzeciwu górników wobec komunistycznej władzy po wprowadzeniu stanu wojennego sprawiły, że Służba Bezpieczeństwa odnotowywała nie tylko działania, które władza uznawała za wrogie wobec ustroju, ale wszelkie wydarzenia zakłócające rytm pracy, zarówno takie, w których dopatrywano się sabotażu, jak i całkowicie przypadkowe zdarzenia. W nowej sytuacji społeczno-politycznej, jaka wytworzyła się w kraju po 1989 roku, działania funkcjonariuszy SB przeszły do historii. W warunkach przejścia do gospodarki rynkowej całe górnictwo czekała trudna restrukturyzacja. Tak jak wspomniano, KWK „Katowice” zakończyła swoją działalność w 1999 roku. W okresie 176 lat swojej działalności wydobyto w niej ponad $120 \mathrm{mln}$ ton węgla. W 2001 roku rozpoczął się proces rewitalizacji terenu pokopalnianego. Zlikwidowano 86 obiektów na powierzchni, przy

${ }^{63}$ IPN Ka 030/414, Analiza sprawy operacyjnego sprawdzenia krypt.[onim] „Saturn” z 24 V 1989 r., k. 41-42.

${ }^{64}$ IPN Ka 030/414, Analiza sprawy operacyjnego sprawdzenia krypt.[onim] „Delta” z 22 V 1989 r., k. 44-45. 
czym pozostawiono kilkanaście przedstawiających największą wartość historyczną i zabytkową. Obiekty te wraz z całym terenem kopalni stanowią katowicką „Strefę Kultury”, w której wybudowano Międzynarodowe Centrum Kongresowe, nową siedzibę Muzeum Śląskiego oraz siedzibę Narodowej Orkiestry Symfonicznej Polskiego Radia ${ }^{65}$.

\section{BIBLIOGRAFIA}

\section{Archiwalia}

Archiwum Instytutu Pamięci Narodowej, Oddział w Katowicach

IPN Ka 030/414, SO „Carbon”.

IPN Ka 036/1739, SOS „Gosia”.

IPN Ka 043/1017, KE „Beta”.

IPN Ka 048/197, SOS „Mars”.

IPN Ka 048/576, SOR „Brzoza”.

IPN Ka 048/633, KE „Jowisz”.

IPN Ka 048/1210, SOR „Alfa”.

IPN Ka 048/1860, SOS „Gama”.

IPN Ka 230/2962.

IPN Ka 230/2998, KE „Beta” (!).

IPN Ka 0055/1559, t. 1-2, Teczka personalna i teczka pracy tajnego współpracownika pseudonim „Pilot”.

IPN Ka 00250/95, t. 1-3, Teczka personalna i teczka pracy tajnego współpracownika pseudonim „Karol”.

IPN Ka 0055/1371, t. 1-2, Teczka personalna i teczka pracy tajnego współpracownika pseudonim ,Jurek”.

IPN Ka 0055/1491, t. 1-2, Teczka personalna i teczka pracy tajnego współpracownika pseudonim „Kornakowicz”.

IPN Ka 0055/1492, t. 1-2, Teczka personalna i teczka pracy tajnego współpracownika pseudonim „Zyga”.

IPN Ka 0062/803, t. 1-2, Teczka personalna i teczka pracy tajnego współpracownika pseudonim „Sylwek”.

IPN Ka 00233/3990, Teczka personalna.

IPN Ka 00250/148 t. 1-2, Teczka personalna i teczka pracy tajnego współpracownika pseudonim „Kuba”.

IPN Ka 00250/147, Teczka personalna.

IPN Ka 0055/1435, t. 1-2, Teczka personalna i teczka pracy tajnego współpracownika pseudonim „Krzyś”.

${ }^{65} \mathrm{https}$ ://fotopolska.eu/Kopalnia_Wegla_Kamiennego_Katowice_Katowice; https://sbc.org.pl/ Content/197823/O_eksploatacji_wegla_w_obszarze_centrum_Katowic_150_35.pdf; https://www.geosi-

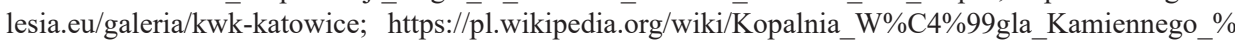
E2\%80\%9EKatowice\%E2\%80\%9D, (dostęp: 15.06.2020). 
IPN Ka 0055/1469, t. 1-2, Teczka personalna i teczka pracy tajnego współpracownika pseudonim „Piotrek”.

IPN Ka 0055/1563, t. 1-2, Teczka personalna i teczka pracy tajnego współpracownika pseudonim „Górnik”.

IPN Ka 00233/3985, Teczka personalna.

IPN Ka 0055/1506, t. 1-2, Teczka personalna i teczka pracy tajnego współpracownika pseudonim ,Borys”.

IPN Ka 0055/1493, Teczka personalna.

IPN Ka 00233/4000, t. 1-2, Teczka personalna i teczka pracy tajnego współpracownika pseudonim „Adaś”.

IPN Ka 0055/1327, t. 1-2, Teczka personalna i teczka pracy tajnego współpracownika pseudonim „Francek”.

IPN Ka 0055/1434, t. 1-2, Teczka personalna i teczka pracy tajnego współpracownika pseudonim „Kazek”.

IPN Ka 0055/1558, t. 1-2, Teczka personalna i teczka pracy tajnego współpracownika pseudonim „Kornel”.

\section{Opracowania}

150 lat kopalni węgla kamiennego „Katowice”, oprac. zespół pod przewodnictwem F. Ciska, Katowice 1973.

Borowy R.W., Wczoraj-dziś - jutro... kopalni „Katowice-Kleofas”. Historia węglem pisana, Katowice 1997.

Chojecka E., Wincenty Pstrowski - zabrzański bohater pracy - tragiczny [w:] Praca, jej rola i funkcje społeczne na przestrzeni wieków w kontekście Europy Środkowej, red. A. Barciak, Katowice-Zabrze-Rybnik 2018, s. 158-162.

Dwilewicz Ł., Polityka energetyczna PRL [w:] Problemy energetyczne Polski, cz. I: Surowce, red. A. Jarosz-Nojszewska, W. Morawski, Warszawa 2016.

Gisman S., Stownik górniczy, Katowice 1949.

Grzegorek G., Frużyński A., Rygus P., Kopalnie i huty Katowic, Katowice 2017.

Jezierski A., Leszczyńska C., Historia gospodarcza Polski, Warszawa 1997.

Landau Z., Tomaszewski J., Zarys historii gospodarczej Polski 1918-1939, Warszawa 1981.

Łazor J., Import i eksport polskiego wegla w okresie międzywojennym [w:] Problemy energetyczne Polski, cz. I: Surowce, red. A. Jarosz-Nojszewska, W. Morawski, Warszawa 2016.

Maroszek H., Kopalni Węla Kamiennego „,Katowice”1823-1988, Katowice 1988.

Musiał F., Podręcznik bezpieki. Teoria pracy operacyjnej Stużby Bezpieczeństwa w świetle wydawnictw resortowych Ministerstwa Spraw Wewnętrznych PRL (1970-1989), Kraków 2007.

Obsada stanowisk kierowniczych aparatu bezpieczeństwa w województwach śląskim/katowickim, bielskich i częstochowskim, wstęp i red. W. Dubiański, A. Dziuba, A. Dziurok, Katowice 2009.

Terlecki R., Miecz i tarcza komunizmu. Historia aparatu bezpieczeństwa w Polsce 1944-1990, Kraków 2007.

Woźniczka Z., Represje na Górnym Śląsku po 1945, Katowice 2010. 
Woźniczka Z., Dewastacja Górnego Śląska w 1945 roku przez Armię Czerwona [w:] Z dziejów przemystu po 1945 roku, red. E. Kościk, R. Klementowski, Wrocław 2012, s. $123-138$.

Woźniczka Z., Praca przymusowa w Polsce po 1945 roku [w:] Praca, jej rola i funkcje społeczne na przestrzeni wieków w kontekście Europy Środkowej, red. A. Barciak, Katowice-Zabrze-Rybnik 2018, s. 271-292.

\section{Źródła internetowe}

1980, http://www.solidarnosc.krakow.pl/?q=node/149 (dostęp: 12.05.202).

https://sbc.org.pl/Content/197823/O_eksploatacji_wegla_w_obszarze_centrum_Katowic_150_35.pdf (dostęp: 10.05.2020).

https://www.geosilesia.eu/galeria/kwk-katowice (dostęp 15.05.2020).

Kopalnia Węgla Kamiennego" Katowice”, https://fotopolska.eu/Kopalnia_Wegla_Kamiennego_Katowice_Katowice (dostęp: 10.05.2020).

Kopalnia Węgla Kamiennego „Katowice”, https://pl.wikipedia.org/wiki/Kopalnia_W\%C4\% 99gla_Kamiennego_\%E2\%80\%9EKatowice\%E2\%80\%9D (dostęp: 12.05.2020).

Miłoch R., Uchwała Rady Ministrów $n r$ 199/81, http:/www.encysol.pl/wiki/Uchwa\% C5\%82a_Rady_Ministr\%C3\%B3w_nr_199/81 (dostęp: 15.05.2020). 